DOI: https://doi.org/10.31933/jemsi.v2i2 Received: 5 November 2020, Revised: 15 November 2020, Publish: 30 November 2020

$\begin{array}{|ll|} & \text { JEMSI } \\ & \text { JURNAL EKONOMI MANAJEMEN }\end{array}$

\title{
REKRUTMEN DAN SELEKSI KARYAWAN DENGAN METODE PENJARINGAN DI LEMBAGA PENDIDIKAN BERDAMPAK TERHADAP KINERJA KARYAWAN DI NIBRAS HOUSE SIDOREJO (STUDI PADA KARYAWAN NIBRAS HOUSE SIDOREJO LAMPUNG TIMUR)
}

\author{
Rini Endrayani \\ Fakultas Ekonomi Universitas Terbuka, riniendrayani079@gmail.com \\ Corresponding Author: Penulis Pertama
}

\begin{abstract}
Abstrak: perencanaan MSDM pada suatu perusahaan mempertimbangkan beberapa faktor diantaranya pola rekrutmen, pada Nibras House Sidorejo pola rekrutmen yang digunakan yaitu dengan penjaringan di lembaga pendidikan, rekrutmen pola ini sebagai antisipasi terjadinya : Kurang dipahaminya proses penjualan retail oleh karyawan, karyawan belum terbiasa bekerja di dalam ruangan atau toko dan karyawan belum mampu mengelola toko dengan baik. Dari permasalahan yang terjadi maka Nibras House Sidorejo membuat suatu terobosan dengan melibatkan lembaga pendidikan sebagai partner dalam proses rekrutmen, terobosan metode ini dikenal dengan istilah program Nibras class untuk peserta didik SMK dengan program keahlian Bisnis Daring Pemasaran (BDP). Dari hasil pengamatan dapat dinyatakan bahwa dengan program Nibras class perusahaan mendapat beberapa keuntungan : Mendapatkan karyawan siap kerja di bidang bisnis retail, Hasil program Nibras class memiliki kompetensi tinggi bekerja, Secara psikologis karyawan sudah menyatu dengan perusahaan dalam beberapa tahun dan Perusahaan tidak perlu lagi membuat program rekrutmen karyawan.
\end{abstract}

Kata kunci: rekrutmen, kompetensi, nibras class, kinerja karyawan.

\section{PENDAHULUAN}

\section{Latar Belakang Masalah}

Perencanaan strategis merupakan perncanaan yang telah mempertimbangkan berbagai macam faktor dan mengusulkan beberapa alternatif perencanaan sebagai solusi untuk memecahkan masalah perusahaan. (Sobirin, 2016) Dalam perencanaaan perusahaan meliputi perncanaan bisnis, produksi, SDM, marketing dan lain-lain, tetapi dalam Artikel ini akan dibahas tentang perencanaan rekrutmen karyawan perusahaan.

Antisipasi jumlah ideal karyawan dalam suatu perusahaan merupakan hal yang sangat sulit, maka setiap perusahaan harus mampu membuat suatu analisa dan perkiraan rekrutmen 
pada tahun berikutnya dengan akurat. Dari hasil analisis didapatkan formasi lowongan pekerjaan dengan melalui penarikan SDM atau rekrutmen.

Penarikan SDM diartikan sebagai semua kegiatan organisasi yang dirancang untuk mempengaruhi jumlah orang - orang yang akan melamar lowongan, tipe tipe orang yang melamar untuk itu, dan/atau kemungkinan bahwa mereka yang mengisi lowongan akan menerima posisi yang diberikan. Tujuan dari diadakanya rekrutmen adalah untuk menjamin bahwa ketika terjadi ada lowongan, organisasi sudah memiliki sejumlah pelamar berkualitas masuk akal untuk dipilih. Untuk mendapatkan karyawan yang berkualitas maka rekrutmen dapat dimulai setelah mengetahui persyaratan dan kualifikasi pelamar.

Metode perekrutan karyawan baru oleh suatu perusahaan :

1. Eksternal

a) Lembaga pendidikan

b) Teman/anggota keluarga karyawan.

c) Lamaran terdahulu yang telah masuk

d) Agen tenaga kerja

e) Karyawan perusahaan lain

f) Asosiasi profesi

g) Outsourcing

2. Internal

a) Promosi

b) Transfer / rotasi

c) Pengkaryaan karyawan kembali

d) Kelompok pekerja sementara / karyawan kontrak ( temporer )

Metode perekrutan karyawan dengan sumber dari luar perusahaan, dapat dilakukan :

1) Melalui iklan di media massa (radio, TV, koran, internet).

2) Melalui iklan atau advertensi diharapkan perusahan dapat merekrut calon tenaga kerja dengan spesifikasi tertentu dan dengan pengalaman kerja tertentu. Perekrutan melalui iklan ini biasanya disertai dengan suatu janji yang menarik, misalnya gaji yang besar, masa depan yang menarik dan sebagainya. 
3) Open house, untuk menjaring lebih banyak tenaga potensial secara umum, perusahaan dapat melakukan open house di sejumlah kalangan yang diprediksikan dapat menarik calon tenaga kerja potensial, seperti di perguruan tinggi, even-even tertentu.

4) Menyewa konsultan perekrutan. Terkadang untuk mencari dan merekrut tenaga kerja profesional dibutuhkan konsultan yang mampu mencari tenaga tersebut, dengan demikian ada jaminan melalui konsultan perekrutan perusahaan tidak perlu membuang waktu untuk mencari tenaga kerja yang sesuai. (Sondang, 2010)

Dari pemaparan di atas maka sangatlah jelas metode yang digunakan dalam proses rekrutmen, suatu perusahaan hanya tinggal memilih salah satu metode ataau beberapa metode dalam proses rekrutmennya.

Pada Artikel ini akan dibahas tentang rekrutmen karyawan Nibras House Sidorejo di propinsi lampung, dalam Artikel ini akan dibahas tentang rekrutmen karyawan marketing sehingga menarik untuk dibahas.

\section{Rumusan Masalah}

Pada beberapa perusahaan proses keluar dan masuk karyawan sering terjadi hal ini disebabkan beberapa faktor, diantaranya : gaji, pemahaman karyawan tentang bisnis perusahaan, menolak peraturan yang berlaku dan hubungan dengan pimpinan perusahaan atau teman sejawat. Dari permasalahan itu Nibras House Sidorejo melakukan terobosan dengan program rekrutmen dari lembaga pendidikan serta memberikan materi marketing tentang Nibras sejak calon karyawan duduk di kelas 10 SMK.

Bagaimana hasil rekrutmen karyawan Nibras House Sidorejo dengan menggunakan metode input dari lembaga pendidikan?

\section{KAJIAN PUSTAKA}

Definisi Rekrutmen

Ada beberapa pengertian rekrutmen menurut para ahli:

1. Menurut Henry Simamora (1997:212) dalam buku koleksi digital Universitas Kristen Petra menyatakan bahwa: 
Rekrutmen adalah serangkaian aktivitas mencari dan memikat pelamar kerja dengan motivasi, kemampuan, keahlian, dan pengetahuan yang diperlukan guna menutupi kekurangan yang diidentifikasi dalam perencanaan kepegawaian.

2. Menurut Randall S. Schuler dan Susan E. Jackson (1997:227) dalam Nanang Nuryanta (2008)

Rekrutmen antara lain meliputi upaya pencarian sejumlah calon karyawan yang memenuhi syarat dalam jumlah tertentu sehingga dari mereka perusahaan dapat menyeleksi orang-orang yang paling tepat untuk mengisi lowongan pekerjaan yang ada.

3.Menurut Schermerhorn, 1997

Rekrutmen (Recruitment) adalah "proses penarikan sekelompok kandidat untuk mengisi posisi yang lowong. Perekrutan yang efektif akan membawa peluang pekerjaan kepada perhatian dari orang-orang yang berkemampuan dan keterampilannya memenuhi spesifikasi pekerjaan.

\section{Menurut Faustino Cardoso Gomes (1995:105)}

Rekrutmen merupakan proses mencari, menemukan, dan menarik para pelamar untuk dipekerjakan dalam dan oleh suatu organisasi. Rekrutmen merupakan proses komunikasi dua arah. Pelamar-pelamar menghendaki informasi yang akurat mengenai seperti apakah rasanya bekerja di dalam organisasi bersangkutan. Organisasi-organisasi sangat menginginkan informasi yang akurat tentang seperti apakah pelamar-pelamar tersebut jika kelak mereka diangkat sebagai pegawai.

5. Menurut Noe at. all ( 2000 )

Rekrutmen didefinisikan sebagai "pelaksanaan atau aktifitas organisasi awal dengan tujuan untuk mengidentifikasi dan mencari tenaga kerja yang potensial.

Calon tenaga kerja yang akan direkrut dapat diambil dari internal organisasi maupun eksternal organisasi. Perekrutan tenaga kerja dari dalam biasanya dilakukan oleh organisasi/perusahaan yang telah lama berjalan dan memiliki sistem karier yang baik. Perekrutan tenaga kerja dari dalam memiliki keuntungan, diantaranya adalah tidak mahal, promosi dari dalam dapat memelihara loyalitas dan dedikasi pegawai, dan tidak diperlukan masa adaptasi yang terlalu lama, karena sudah terbiasa dengan suasana yang ada. Namun 
demikian perekrutan dari dalam juga berarti terjadinya pembatasan terhadap bakat yang sebenarnya tersedia bagi organisasi dan mengurangi peluang masuknya pemikiran baru.

\section{Proses Rekrutmen Karyawan Marketing Nibras House Sidorejo}

Nibras House Sidorejo merupakan cabang dari Nibras Lampung yang merupakan perusahaan yang bergerak di bidang retail pakaian muslim, yang menyediakan baju segala usia baik pria atau wanita, seirirng perkembangan waktu outlet outlet kompetitor sanagtlah banyak maka diperlukan tenaga kerja atau karyawan yang ber kompetensi tinggi.

Pada rekrutmen yang biasa diterapkan informasi lowongan disampaikan dengan pamflet yang di tempel pada dinding atau kaca toko, kemudian pelamar mengirimkan surat lamaran beserta persyaratan untuk memenuhi kualifikasi yang sudah ditentukan perusahaan, setelah itu dilaksanakan tes yang meliputi tes fisik, pengetahuan, kesehatan dan psikotes. Setelah selesai tes dilakukan pengumuman bagi peserta tes yang lulus kemudian melengkapi persyaratan karyawan dan tanda tangan kontrak.

\section{Kinerja Karyawan}

Kinerja Karyawan Menurut Veithzal mengemukakan bahwa: "Kinerja merupakan perilaku nyata yang ditampilkan setiap orang sebagai prestasi kerja yang dihasilkan oleh karyawan merupakan suatu hal yang sangat penting dalam upaya perusahaan untuk mencapai tujuannya (Bintoro \& Daryanto, 2017). Menurut sedamayanti kinerja karyawan adalah sebuah hasil kerja yang telah dicapai oleh pegawai aau karyawan yang sesuai dengan kriteria maupun standar yang sebelunya telah ditetapkan pada periode tertentu (Heryenzus \& Laia, 2018: 15). Berdasarkan pengertian kinerja menurut para ahli di atas, maka dapat disimpulkan bahwa kinerja merupakan suatu prestasi kerja baik kuantitas maupun kualitas yang dicapai oleh seorang karyawan dalam melaksanakan tugas kerjanya sesuai degan tanggung jawab yang diberikan oleh perusahaan kepadanya. Menurut padangan Robbins indikator kinerja karyawan, yaitu: Sherlie, Hikmah 757 MOTIVASI Jurnal Manajemen dan Bisnis Volume 5, Nomor 1 2020 (Bintoro \& Daryanto, 2017) : (1) Kualitas. (2) Kuantitas. (3) Ketepatan Waktu. (4) Efekivitas. (5) Kemandirian. (Sherlie, 2020).

Kinerja karyawan juga selalu berhubungan dengan apa yang mereka dapatkan dari perusahaan bisa berupa kompensasi. (Hani Handoko1) (2003:155), kompensasi adalah segala sesuatu yang diterima para karyawan sebagai balas jasa untuk kerja mereka Upah atau gaji pokok adalah pembayaran yang diterima karyawan secara bulanan, mingguan, atau setiap jam sebagai hasil dari pekerjaan mereka. Insentif merupakan imbalan yang ditambahkan terhadap 
upah atau gaji dan biasanya berkaitan secara langsung dengan prestasi kerja, ( seperti : bonus, komisi, profit sharing, piece rate plans). Sedangkan benefit adalah imbalan yang diterima karyawan sebagai hasil dari pekerjaan dan posisi mereka dalam organisasi, ( seperti pembayaran hari libur, asuransi kesehatan, asuransi jiwa, dan tunjangan pensiun). Pembayaran (pay) adalah penerimaan karyawan secara nyata sebagai hasil dari pekerjaan mereka. Dari penjelasan yang telah diuraikan, dapat disimpulkan bahwa, kompensasi adalah suatu balas jasa yang diberikan oleh perusahaan kepada karyawan dalam rangka kontribusi yang diberikan dalam bentuk, seperti upah atau gaji, reward, insentif atau bonus, komisi, dan lainlain.Pemberian kompensasi yang diberikan diterima oleh karyawan secara bulanan, mingguan, atau setiap jam sebagai hasil dari pekerjaan sesuai dengan pengorbanan waktu, tenaga, pikiran yang telah mereka berikan kepada perusahaan. (Qustolani, 2017)

\section{METODE PENULISAN}

Metode penulisan artikel ilmiah ini dengan metode kualitatif, mengkaji buku-buku literatur yang sesuai dengan teori yang dibahas khususnya dilingkup Sumber Daya Manusia serta melakukan observasi di lapangan, sehingga dalam penulisan ini terjadi pembauran metode yaitu studi literatur dan observasi. Teori yang timbul dari studi literatur diimplementasikan paada observasi lapangan.

Pada penelitian ini tahap pra penelitian meliputi pencarian masalah yang berkaitan dengan rekrutmen dan kinerja karyawan di Niobras House Sidorejo, dilanjutkan dengan mencari permasalahan penelitian melalui bahan tertulis (jurnal), dan berdiskusi dengan pemilik Nibras House Sidorejo melalui wawancara.

\section{PEMBAHASAN}

Artikel ini menanalisa dan membahas tentang variabel-variabel Manajemen Sumber Daya Manusia yaitu sistem rekrutmen dan kinerja karyawan. Artikel sebelumnya yang relevan dengan artikel ini adalah :

Berdasarkan artikel dari Ellyta Y, maka diperoleh : pertama ditemukanbahwa seleksi signifikan dipengaruhi oleh rekrutmen yang mencakup perencanaan dan waktu pelaksanaan rekrutmen. Kedua, ditemukan bahwa kinerja dipengaruhi secara signifikan oleh seleksi yang tercermin dari prosedur seleksi, peserta seleksi, dan pelaku seleksi. Ketiga, rekrutmen memengaruhi secara tidak langsung terhadap kinerja melalui proses seleksi. Hasil ini berbeda dengan temuan sebelumnya, yang menyatakan bahwa rekrutmen berpengaruh langsung terhadap kinerja. Tingkat generalisasi kinerja organisasi yang dipengaruhi oleh rekrutmen dan 
seleksi hanya berlaku pada konteks penelitian ini, dan belum tentu berlaku pada bagian lainnya. (Yullyanti, 2009)

\section{Metode Rekrutmen Karyawan Nibras House Sidorejo Menggunakan Lembaga Pendidikan}

Konsep rekrutmen berbasis kompetensi memberikan beberapa keunggulan, antara lain tingkat akurasi yang tinggi dalam menilai tepat tidaknya seseorang ditempatkan pada pekerjaan yang berbeda-beda sesuai potensi yang dimiliki, memfasilitasi kesesuaian antara keterampilan seseorang dengan minat dan kebutuhan kerja, mencegah interviewer dan assesor melakukan penilaian sesaat terhadap calon tenaga kerja hanya dengan melihat penampilan dan karakteristik luarnya. Proses seleksi yang berjenjang terencana dan distandarisasi dengan beberapa metode dan teknim seleksi diharapkan menghasilkan kandidat terpilih yang benarbenar memiliki kompetensi sesuai dengan spesifikasi pekerjaan. (Fathillah, 2016)

Dari hasil riset di atas maka Nibras House Sidorejo melakukan anallisa terhadap Proses mutasi keluar dan masuk karyawan di Nibras House Sidorejo sering terjadi, adapun penyebab diantaranya akibat :

1. Kurang dipahaminya proses penjualan retail oleh karyawan

2. Karyawan belum terbiasa bekerja di dalam ruangan atau toko

3. Karyawan belum mampu mengelola toko dengan baik.

Dari permasalahan yang terjadi maka Nibras House Sidorejo membuat suatu terobosan dengan melibatkan lembaga pendidikan sebagai partner dalam proses rekrutmen dengan basis kompetensi, terobosan metode rekrutmen ini dikenal dengan istilah program Nibras class untuk peserta didik SMK dengan program keahlian Bisnis Daring Pemasaran (BDP).

\section{Prosedur Pelaksanaan Nibras Class}

Program Nibras class merupakan kerjasama antara pengelola program keahlian Bisnis Daring Pemasaran dengan Nibras House Sidorejo, program ini dimulai dengan diskusi bersama antara pihak sekolah dengan perusahaan, adapun rangakian program seperti berikut :

1. Penandatanganan MoU atau nota kesepahaman kerjasama antara Nibras House Sidorejo dengan sekolah

2. Sinkronisasi kurikullum antara Nibras House Sidorejo dengan sekolah

3. Rekrutmen peserta program dari peserta didik kelas 11 
4. Supervisi pelaksanaan program dari perusahaan ke sekolah

5. Praktik kerja lapangan di toko Nibras House Sidorejo

Pada pelaksanaan program Nibras class peserta direkrut dari kelas 11 sehingga memiliki waktu selama dua tahun untuk belajar tentang toko Nibras, setelah melalui proses pendidikan, pemagangan (PKL) selama 3 bulan sampai 6 bulan dan uji kompetensi maka peserta sudah sangat memahami bisnis retail di toko Nibras House Sidorejo

\section{Hasil Program Nibras Class}

Setelah berjalan selama tiga tahun program Nibras class telah mendapatkan hasil, peserta program langsung bekerja di toko-toko Nibras House sidorejo tanpa melalui seleksi lagi, artinya perusahaan tidak perlu melakukan rekrutmen ulang untuk peserta program Nibras class. Dari hasil pengamatan dapat dinyatakan bahwa dengan program Nibras class perusahaan mendapat beberapa keuntungan :

1. Mendapatkan karyawan siap kerja di bidang bisnis retail

2. Hasil program Nibras class memiliki kompetensi tinggi bekerja.

3. Secara psikologis karyawan sudah menyatu dengan perusahaan dalam beberapa tahun.

4. Perusahaan tidak perlu lagi membuat program rekrutmen karyawan.

5. Kinerja karyawan hasil rekrutmen dari lembaga pendidikan cenderung terus meningkat.

Dari keuntungan tersebut di atas maka sangatlah penting program rekruitmen dengan melibatkan lembaga pendidikan untuk menghasilkan karyawan dengan kompetensi tinggi, mau bekerja keras, dan memiliki loyalitas tinggi kepada perusahaan.

\section{KESIMPULAN \& SARAN}

\section{Kesimpulan}

Berdasarkan hasil pembahasan maka dapaat disimpulkan untuk membangun suatu hipotesis guna untuk riset selanjutnya seperti di bawah ini :

1. Rekrutmen Nibras class dilaksanakan pada saat peserta masih kelas 10 sehingga ada 3 tahun waktu untuk belajar tentang Nibras.

2. Program pembelajaran Nibras class sudah didesign seperti kondisi sebenarnya di tokotoko Nibras sehingga didapatkan karyawan dengan kompetensi tinggi

3. Keluar masuk karyawan di Nibras dapat teratasi dengan pelaksanaan Nibras class karena pada program ini akan didapatkan karyawan dengan loyalitas tinggi. 
4. Program Nibras class mampu menekan biaya rekrutmen dan pelatihan karyawan karena karyawan baru sudah tidak dilaksanakan lagi tes dan pelatihan untuk jadi karyawan Nibras.

5. Hasil pengamatan kinerja karyawan hasil nibras class sangat signifikan perkembanganya akibat dari proses pembentukan kompetensi di lembaga pendidikan.

\section{Saran}

Berdasarkan kesimpulan di atas, maka saran pada artikel ini adalah masih banyak faktor lain yang mempengaruhi kinerja karyawan, oleh sebab itu masih dibutuhkan kajian lebih lanjut untuk melengkapi faktor-faktor apa saja yang mempengaruhi kinerja.

\section{BIBLIOGRAHY}

Fathillah, F. (2016). Rekrutmen dan Seleksi Berbasis Kompetensi : tantangan Pemenuhan Tenaga Kerja Berkualitas.

Qustolani, A. (2017, Juli-Desember). Pengaruh Kepuasan Kerja, Keadilan Prosedural dan Kompensasi terhadap Kinerja Karyawan.

Sherlie. (2020, Februari 18). Pengaruh motivasi, Disiplin Kerja dan Kompensasi terhadap Kinerja Karyawan PT Benwin Indonesia di Kota Batam.

Sobirin, A. (2016). Modul Manajemen Kinerja.

Sondang, P. (2010). Manajemen Sumber Daya Manusia.

Yullyanti, E. (2009). Analisa Proses Rekrutmen dan Seleksi pada Kinerja Pegawai. Jurnal Ilmu Administrasi dan Organisasi, 16, 3. 